\title{
El hilo más intenso de la memoria
}

\author{
Por Diamela Eltit
}

La medida cronológica del tiempo es una ficción. Lo es porque el tiempo es multiforme, nunca lineal, sin principio ni fin. Transcurre de espaldas a cualquier cronología pero, en el interior de esta clasificación convencional del tiempo — sus códigos y sus signos - se escriben las huellas que establecen los sucesos. Allí se fijan los hitos que marcan puntos de inflexión para trazar la línea histórica establecida por los pactos sociales.

La antigua leyenda de la Caperucita Roja se convirtió en cuento infantil. Un relato que puso y expuso a la niña, derribó a la abuela, marcó las estrategias demoledoras del lobo y advirtió que las niñas están en peligro ante cualquier bosque (me refiero al acecho imponente de los árboles). Porque en los cuentos, digamos, clásicos, el lobo se come a la abuela y se apresta a caer sobre la niña. Lo que está en el centro de este relato es la genealogía de mujeres, la siempre peligrosa, milenaria, circulación de las niñas, el simulacro, la devoración.

Alejandra del Río, atraviesa los siglos, retrocede, se detiene en esa precisa narrativa infantil y construye un texto poético donde descentra los cuerpos, los repiensa, los desplaza, los convoca. Con indiscutible maestría, traslada el rojo hasta convertirlo en un hilo de sangre como lugar protagónico. Rompe así la épica masculina de la guerra y la herida y deposita en la sangre menstrual de la mujer la trama que tiñe el rojo-caperucita. De esa manera estalla la poética que atraviesa el poema. Administra y disemina la letra hasta que la sangre adquiere la calidad de soporte del relato.

La capucha es el signo que ordena lo clandestino. La Caperucita muta en capuchita y se desplaza con el lobo, esta vez compañero, escudado en su piel de oveja. Un lobo invadido por una erótica corporal y política que permite vislumbrar la opresión y el crimen. El poema caperuza se refugia clandestino en los años de la dictadura, la peligrosa circulación de los cuerpos, el padre comunista, los pasos sigilosos, el peligro.

Alejandra del Río trabaja la memoria desde un lugar inesperado que es, a su vez, preciso. El texto da cuenta de la violencia, indica la estrategia y el camuflaje que se requiere para pervivir. Desde el cuento infantil, a partir de su imagen reconocible, se desencadena un trabajo literario sorprendente que reteje el cuento hasta conver- 
tirlo en un patrimonio sudamericano de la resistencia-niña deambulando por un bosque otro. Un bosque Igualmente tenebroso.

Este texto poético escoge la familia como centro de habla, pero se trata de una familia que se encarna en un poderoso y hasta macabro relato infantil como un modo de protección y de fuga ante el tiempo que les corresponde enfrentar. Habitan en un bosque periférico y amenazante que requiere de la máscara proporcionada por la capuchita. Así la mujer capucha se erige como la protagonista de una historia de sobrevivencia. Pero en este cuento negro y rojo, en medio de esta precisa trama capucha, el lobo es repensado, revaluado, erotizado. El lobo forma parte del pacto.

El tiempo histórico lo protagoniza la dictadura. Los últimos años que contienen los primeros. Esos años del texto marcan un final y la salida. Años de resistencia de la familia capucha, años de ira y de duelo ante una maquinaria pensada para destruir. Después, cuando ha terminado el largo acoso dictatorial, se abre un escenario detenido, neutro, algo así como un reloj digital que anunciara de manera burocrática la parte más tediosa de una simple repetición.

Pero hoy, la publicación de este libro permite ver cómo se une, se amalgama, prolifera el tiempo, especialmente el de la violencia estatal. No se puede separar el texto, su cuidadosa escritura y su habitar periférico, del último presente que vivimos. Este tiempo atiborrado de pasado que se hará centro en un futuro. Se trata una vez más de pensar el bosque, el lobo y la niña y cómo no a la abuela en su cama. Las carencias.

Habría que unir los años que mueven el poema de Alejandra del Río con la poética de pobreza y resistencia de todos los tiempos. El tiempo de hoy, el que transcurre ahora mismo. Quizás se podría pensar, a partir de la propuesta literaria de "Capuchita Negra" que la Caperucita-capucha estuvo dormida en el bosque junto a su abuela durante unos años en los que propusieron descansar para recuperar o afinar o reparar sus fuerzas y ajustar sus capuchas. Que en el año 2018, el año de la insurrección capucha de las mujeres jóvenes, partió una época nueva para una gran cantidad de caperuzas. Que una multitud de ellas salieron del bosque. Que más adelante, se plegaron a los otros y a las otras de manera necesaria, sin capitular, después de ejercer una forma de descanso.

Porque las caperuzas, ya organizadas, denunciaron a los asaltantes del bosque y de las niñas y volvieron a ponerse sus capuchas, la misma que poetiza Alejandra del Río. Que ellas, como protagonistas de una escena innegable, se juntaron con los buenos lobos que adoptaron su capucha para resistir.

En el texto poético de Alejandra de Río, se levantan los lobos-compañeros (dejemos afuera los soplones, a los invasores) y cuánto le deben ellos a las capu- 
chitas negras, le deben el equilibro y la equidad, le deben la madre y a la abuela de la caperuza-capuchita. Le deben alcanzar la equidad de su capucha y de su marcha. Le deben al libro "Capuchita Negra" que de manera brillante elaboró Alejandra del Río pensando en el ayer, en la memoria y su repetición. Una memoria que es necesario entender para enfrentar el presente de una manera luminosa, sin bosques que interrumpan el buen curso de la luz y de la brisa. Porque, como dice el poema: "deja la puerta abierta a la fragilidad/ y los que están rotos/ se harán fuertes mientras sigan juntos”.

Junio 2020 